\title{
Hol van az igazság? - Görögkatolikus egyházi fenntartású középiskolás fiatalok igazságossággal kapcsolatos értékei
}

\author{
BENCZE ÁDÁM ${ }^{1}$
}

\begin{abstract}
ABSZTRAKT
A tanulmányunk célja annak bemutatása, hogy a megkérdezett fiatalok mit gondolnak az igazságosságról, és mennyiben különböznek a hazai ifjúságtól és a magyar társadalom egészétôl. Egy társadalom jó múködéséhez szükséges, hogy benne a viszonyok igazságosak legyenek. Azonban többféle igazságosság létezik. Az, hogy a fiatalok, mint a jövő felnőttjei, mit gondolnak erről az értékről, alapvető fontosságú a társadalom múködése szempontjából. A tanulmányban bemutatjuk az igazságossággal kapcsolatos filozófiai értelmezéseket és értékszociológiai kutatásokat, majd meghatározzuk a magyar fiatalok és a magyar társadalom igazságosságfelfogását. A kutatásunkban megkérdeztük egy kelet-magyarországi görögkatolikus középiskola minden tizenegyedikes és tizenkettedikes diákját 2014-ben és 2019-ben. Kvantitatív módszerrel vetettük össze a tanulók igazságosságról alkotott nézeteit az országban élő többi fiatal elképzeléseivel. Eredményeink szerint a kutatás öt éve alatt a fiataloknak fontosabb lett az egyenlöség, különösen a fiúknak. Az egyenlöség értékének fontossága egyértelmüen összefüggött a megkérdezett fiatalok vallásosságával.
\end{abstract}

KULCSSZAVAK: igazságosság, egyenlőség, szabadság, vallásosság

\section{ABSTRACT}

\section{Where is the truth? - Greek catholic high school youth's justice values}

The purpose of our study is to present what young people think about justice, and how they are different from the youth and society of the country. The functioning of a society requires that fair conditions prevail in it. However, there are several types of justice. What young people, as adults of the future, think about this value is essential for the functioning of a society. We present philosophical interpretations and value sociological research on justice, then we define the concept of justice for Hungarian society and Hungarian youth. In our research we asked all eleventh and twelfth students of a Greek Catholic high school in Eastern Hungary in 2014 and 2019. Quantitative method was used to compare students' views on justice with the other young people in the country. According to our results during the five years of research, equality was more important for young people, especially for the boys. The importance of the value of equality was clearly related to the religiosity of the asked young people.

KEYWORDS: justice, equality, freedom, religiosity

\footnotetext{
${ }^{1}$ Debreceni Egyetem Humán Tudományok Doktori Iskola, Nevelés- és Művelődéstudományi Doktori Program, e-mail: benczeadam324@gmail.com
} 


\section{KÖZELKÉP}

\section{Bevezetés}

A tanulmányunk célja a megkérdezett fiatalok igazságosságról alkotott nézeteinek a bemutatása. Ennek során először az igazságosságot tárgyaló értékszociológiai elméletek történeti ismertetésére, valamint ez alapján az igazságosságértelmezések két fő típusának fogalmi tisztázására kerül sor a szabadság és az egyenlőség viszonyrendszerében. Ezt követően a hazai kutatások alapján felvázoljuk a magyar társadalom és a magyar fiatalok viszonyát e két értékhez, illetve ebből kifolyólag az igazságossághoz. Végül a tanulmányban bemutatjuk a kvázi longitudinális kutatásunkat, melyet egy kelet-magyarországi görögkatolikus egyházi fenntartású középiskolában végeztünk 2014-ben és 2019-ben. Az elemzés során megállapításokat teszünk arra vonatkozóan, hogy a megkérdezett fiatalok hogyan viszonyulnak a szabadság, az egyenlőség, a szolidaritás, a tolerancia és az igazságosság értékeihez.

A tanulmányunkban számos gondolkodóra hivatkozunk Arisztotelésztől Hayekig (Arisztotelész 1987, Hayek 1991), akik szerint egy mindenkori társadalom jó múködéséhez elsősorban arra van szükség, hogy benne a viszonyok igazságosak legyenek. Az igazságosságnak azonban több arca van, többféle megnyilvánulási formája. Az, hogy egy társadalom mit tekint igazságosságnak, az koronként és társadalmanként kisebb-nagyobb mértékben eltérhet. Ugyanakkor ehhez az igazságosságérzethez igazítva az adott társadalom viszonyait, elérhető a társadalom jó múködése, mely jó müködés alapvető viszonyban áll az adott társadalom értékteremtésével, fennmaradásával. Ezek az igazságosságérzetek azonban a világ változásaival változhatnak, átalakulhatnak, amit napjainkban a globalizáció felgyorsít. Egy társadalomban bekövetkező változásokat pedig jól lehet jósolni a felnövekvő fiatalok életfelfogásaival, jelen esetben igazságosságérzeteivel. A tanulmányunkban a fiataloknak egy kisebb csoportjával fogunk foglalkozni, egy görögkatolikus vallásos középiskola tanulóival. A vallásosság befolyásolhatja az alapvető emberi értékekről kialakult képét a válaszoló fiataloknak, amit összehasonlítva az ország fiataljaival rávilágíthatunk a vallásosság szerepére az igazságosságérzetek alakulásában, mely igazságosságérzetek többségéhez való társadalmi-politikai igazodás lehet a társadalom jó működésének, és sikeres fennmaradásának a kulcsa.

\section{Az igazságosság filozófiai megközelítése}

Már az ókori görögök is sokat foglalkoztak a megfelelő társadalom létrehozásával és fenntartásával. Az igazságosságot pedig a kardinális erények közül is a legfontosabbnak találták. Az ókori görög filozófusok szerint ez az egyetlen erény, amit nem lehet rosszra használni. Ugyanis az igazságosság mindig a jóra irányul. Ezért arra jutottak, hogy a boldog polisz feltétele az, hogy benne a viszonyok igazságosak legyenek. De mi volt szerintük az igazságos? Arisztotelész szerint az alapvető törvények és az egyenlőség valamifajta kettőssége. Az igazságos ember pedig tiszteli az alapvető tör- 


\section{KÖZELKÉP}

vényeket és kedveli az egyenlőséget (Arisztotelész 1987, Platón 2008). A későbbi korok filozófusainak egy része azonban nem fogadta el a szabadság és egyenlőség összekapcsolásaként való igazságosságértelmezéseket.

Ilyen filozófiai irányzat az utilitarizmus (haszonelvűség) is, melynek igazságosságértelmezésében nem szerepel az egyenlőség központi helyen. A haszonelvűség Francis Hutcheson skót filozófus (18. század) elvére épül, mely szerint az a hasznos, ami a lehető legnagyobb boldogságot okozza a lehető legtöbb embernek. Erre az egyszerű elvre épített fel a 18. század végén Jeremy Bentham egy egész elméletet: az utilitarizmust. Mivel szerinte minden cselekedet valamilyen örömre vagy valamilyen fájdalom elkerülésére irányul, így ez alapján a legkülönfélébb cselekedetek is összemérhetők egymással. Bentham szerint azt az összörömet kell nézni, amit a cselekedet okozott az egyénnek és másoknak. Ebből következik, hogy a legjobb cselekedet az, ami a legtöbb örömet okozza a legtöbb embernek. A hasznos (a helyes) pedig az öröm (a jó) maximalizálása. Bentham koherens elméletét vitte tovább John Stuart Mill (Mill 1980, Bujalos 2005, Bujalos 2007). Az utilitarista igazságosság tehát azt jelenti, hogy ami a többség számára jó, az egyben igazságos is. Ez a felfogása az 1970-es évekig, John Rawls megjelenéséig, meghatározó volt.

John Rawls (1997) fő művében, Az igazságosság elméletében egy szerinte igazságos társadalmi berendezkedés képét vázolja fel. Egyrészt kritizálja, másrészt élteti a jóléti államot, így ez a máig legerősebb jóléti liberális elmélet. A címből is jól látható, hogy Rawls görög gyökereket követ: az igazságosságot tekinti a társadalom jó működése alapjának. Szerinte a társadalmi intézményeknek az igazságosság olyan, mint a tudománynak az igazság. Egy olyan feltétel, melynek nem teljesülése esetén teljesen mindegy a többi erény. Például egy társadalmi intézmény hiába stabil, biztonságos, hatékony, ha nem igazságos mindezek mellett vagy inkább előtt, akkor Rawls szerint változtatni kell az intézményen, ha nem lehet, akkor pedig meg kell szüntetni (Rawls 1997, Bujalos 2005).

Rawls szerint az igazságosságnak két elve van. Az első egyfajta sérthetetlenségre vonatkozik (mind az állam és mind az állampolgárok között, illetve kölcsönös alapon), a másik pedig arra, hogy az egyenlőtlenségeket kompenzálni köteles a társadalom, az állam. Ez utóbbi elvét Rawls két részre bontotta. Biztosítani kell az állampolgároknak, hogy egyenlő esélyekkel férjenek hozzá a lehetőségekhez és a hatalmakhoz. Továbbá biztosítani kell, hogy a gazdagság egyenlőtlen elosztása a leghátrányosabbak számára előnyös legyen. Rawls így megalkotott egy általa igazságosnak vélt, azaz múködőképes jóléti állami társadalmi berendezkedést (Rawls 1997, Bujalos 2005). Láthatjuk, hogy Arisztotelész és Rawls is a szabadság (Arisztotelésznél törvényesség, Rawlsnál sérthetetlenség) és egyenlőség valamiféle öszszeegyeztetését tekinti az igazságosság alapjának, míg az utilitarista igazságosság igazából egyik említett érték mellett sem áll ki (az az igazságos, ami a többségnek az) (Arisztotelész 1987, Rawls 1997, Bujalos 2005). Azonban van egy másik domináns értelmezése is az igazságosságnak, ami csak a szabadság valamiféle megteremtését 


\section{KÖZELKÉP}

tekinti az igazságosság alapjának, és az egyenlőség értékét elveti. Ilyen igazságosság a libertarianizmus igazságossága.

A libertarianizmus (neoliberalizmus, neokonzervativizmus) atyja Friedrich Hayek, aki a 1929-33-as világválság keynesi megoldására tett alternatív javaslatot. Mindketten a piac következményének gondolták a válságot, de teljesen eltérő megoldást kínáltak rá. John Maynard Keynes az állami beavatkozást és egyfajta „liberális szocializmust" javasolt, míg a szocializmust mélyen kritizáló Hayek a piac még nagyobb kiterjesztését preferálta, ugyanis szerinte a válságot a piac korlátozásai (monopóliumok) okozták. Hayek szerint a piacgazdaság az a rendszer, amelyben a leginkább hasznosulnak az emberek között szétszórt tudások. Ezek a tudások pedig nem egyesíthetők, minden ilyen kísérlet diktatúrához vezet (Hayek 1991, Bujalos 2008, Kovács 2012).

A libertarianizmus egyedüli értékének a szabadságot tekinti, amit csak a törvény korlátozhat, mely az egyénre és az államra ugyanúgy kiterjed. Továbbá Hayek hangsúlyozza még, hogy a szabadságnak csak egy értelmezése lehet, a negatív szabadság, azaz a „nagy tiltások”. Minden más szabadságértelmezés, a pozitív szabadság is, téves a libertarianizmus szerint. Hayek a piac szentségében hitt, ugyanis csak a piac tud létrehozni egy átfogó, spontán rendet, ami egy több központú, létrejött rend. Ezzel szemben a konstruktív racionalizmus csak egy olyan egy-központú létrehozott rendszert tud teremteni, ami elpusztíthatja a szabadságot. Hayek a minimális állam híve volt, így erősen bírálta a jóléti államot, ami szerinte egy „lopakodó szocializmus.” Szerinte a társadalomnak csupán negatív természetű, „nagy tiltásokra” van szüksége, amelyek univerzális helyes magatartási szabályok. A szabadság a kényszer ellentétje, és ez a kényszermentes állapot, amit a szabadság eredményez, a célja a társadalomnak. Hayek szerint nincs is olyan, hogy szociális igazságosság, ugyanis a társadalomban egyáltalán nem is lehetséges igazságosság. Ezért csupán egy dolog szükséges a libertarianista igazságossághoz: szabadság. Az egyenlőség kimarad belőle, mert minden egyenlőség (az esélyegyenlőség is) a szabadság elpusztításához vezet (Hayek 1991, Bujalos 2008, Kovács 2012).

\section{Kétféle igazságosságfelfogás a hazai kutatások tükrében}

Az értékeket sokféleképpen lehet definiálni. Andorka szerint az értékek olyan alapelvek, melyek kifejezik, hogy az adott társadalom mit tart fontosnak (Andorka 2006). Schwarz szerint pedig az értékek elérendő célok, melyek a cselekvések irányító elveiként hatnak (Schwarz 2003). A tanulmányunkban használt értékfelfogáshoz ez a két értelmezés áll a legközelebb.

Értékszociológiai vizsgálatokat az 1970-es évektől végeznek Magyarországon (Hankiss 1977). A kutatások alapján hazánkban erős érték a maszkulinitás, azaz olyan férfias értékek hajtják át a társadalmat, mint a siker vagy a teljesítmény. E mel- 


\section{KÖZELKÉP}

lett erőteljes individualizáció is jellemző a magyarokra, ami szűk keretek közé szorítja a szolidaritás határait. Jellemző még hazánkra a biztonságkeresés, és ezzel párhuzamosan a bizonytalanságkerülés (Hofstede é. n., Schwarz 2003, Bakacsi 2012, Neumann-Bódi - Hofmeister-Tóth - Kopp 2008, Pál 2016). Ezekből a jellemzőkből következtethetünk arra, hogy az egyenlőség - biztonság érzését keltő - értékét fontosabbnak tartják a magyarok, mint a szabadság - lehetőséget adó, de bizonytalanságokat keltő - értékét. Ez afelé mutathat, hogy a bemutatott kétféle igazságosságértelmezés közül hazánkra inkább az egyenlőségpárti igazságosságfelfogás lehet a jellemzőbb. Valamint a maszkulinitás és az individualizmus erős jelenléte a szolidaritás és a tolerancia értékeinek a gyengeségére utalhat.

Tóth István György (2010) a magyar értékszerkezetet vizsgálta Ronald Inglehart világméretű kutatásaiból kiindulva, aki munkatársaival a Nemzetközi Összehasonlító Értékvizsgálat (World Values Survey, WVS) adatait 1981 óta gyűjti (Inglehart 1997, Inglehart - Baker 2000, Inglehart - Welzel 2005). Tóth értékvizsgálatának eredményei szerint Magyarországra az önkifejezési értékek alapján a zárt, a világiracionális értékek alapján a racionális/szekuláris gondolkodásmód jellemző. A mai magyar értékszerkezetre vonatkozóan ez azt jelenti, hogy a nyugat-európai nem posztszocialista országok átlagához viszonyítva kevésbé tartjuk fontosnak a civil és politikai szabadságjogokat, kevésbé toleráljuk a másságot és nagyon kevéssé fogadjuk el az egyenlőtlenségeket (Tóth 2010). Mindeközben Magyarországon, a többi európai országhoz képest, a jövedelmek egyenlőtlensége sem túl nagy, sem túl kicsi (Ward et al. 2009; Tóth 2005; Tóth szerk. 2008). Ugyanakkor a magyarok stabilan, magas arányban értenek egyet azzal, hogy Magyarországon „túl nagyok” a jövedelmi egyenlőtlenségek, amit a felnőtt magyar lakosság 72\%-a rossznak tart (Tóth 2008, Tóth 2010).

A jelenség többek között Erich Fromm Menekülés a szabadság elől című művében kifejtettekkel magyarázható. Fromm szerint a korábbi korszakok védő és korlátozó béklyóitól megszabadult a modern kor embere. Ugyanakkor a szabadság hiába hozta meg számára a várt függetlenséget és racionalitást, ha emellett szorongóvá, elszigeteltté és sok esetben tehetetlenné is tette. A szabadság terhe elől a modern kor embere új függőségekbe vagy alávetettségbe menekülhet (Fromm 2002), melyek felerősíthetik az egyenlőség iránti vágyat. A materialista értékek felerősödésére, a hagyományos értékek eltűnésére, a fragmentált posztmodern értékekre, és az ezekből következő felerősödő bizonytalanságra hazai kutatások is felhívták a figyelmet (Hofmeister-Tóth 2016, Törőcsik 2016). A szabadság esetleges hazai negatív megítélésében ez a nagyfokú bizonytalanság is szerepet játszhat.

Napjainkban két uralkodó igazságosságértelmezés határozza meg e témában a diskurzust, mely felfogások különbségei az egyenlőség radikálisan más értelmezéseiben mutatkoznak meg. „Így két jellemző nézetkombináció keletkezik: az egyenlőtlenség igazságtalan - az egyenlőség igazságos, illetve az egyenlötlenség igazságos - az egyenlöség igazságtalan” (Csepeli - Neményi - Örkény 1992: 349). Látható, hogy 


\section{KÖZELKÉP}

az egyenlőségpárti igazságosság (Rawls) és az egyenlőséget elutasító igazságosság (libertariánus) felfogása teljesen más társadalmat tételeznek fel. Az egyikben az egyenlőtlenségek figyelmen kívül hagyása égbe kiáltó bűn, a másikban éppen az egyenlőtlenségekkel való foglalkozás az, ami elveszi az emberek szabadságát. „,A mai magyar társadalomban azok vannak többségben, akik szerint az egyenlötlenség igazságtalan és az egyenlöség igazságos. Ezzel szemben áll a kisebbség, akik szerint az egyenlőség igazságtalan és az egyenlőtlenség volna az igazságos" (Csepeli - Neményi - Örkény 1992: 349).

Csákó Mihály tizenévesek demokráciaképét vizsgálva szintén kétféle demokráciafelfogást különböztetett meg. A tizenévesek egyik csoportja hajlamosabb a politikai intézményekre és részvételre - azaz a szabadságra - gondolni, amikor demokráciáról van szó. A tizenévesek másik csoportjába olyanok tartoznak, akiknek hamarabb eszébe jut az egyenlőség és a testvériség értékeihez kapcsolódó elemek (Csákó 2007). A 2009-es „Iskola és társadalom” kutatás szerint az egyenlőséghez jobban kapcsolódó demokráciaértelmezést az átlagosnál jobban preferálták a lányok, míg a szabadsághoz jobban kapcsolódó demokráciaértelmezést a fiúk (Murányi 2016).

A Magyar Ifjúság 2016²-ban a résztvevő fiatalok közül a 16 és 19 éves kor közöttieket hasonlítjuk össze az általunk megkérdezett hasonló korú tanulókkal. A magyar fiatalok (16-19 éves) a szabadságot és az egyenlőséget is, mint az emberek életviteléhez kapcsolódó értékeket, teljes mértékben fontosnak ítélték meg, azonban a kapott átlagokból arra következtethetünk, hogy a szabadságot $(4,5)$ fontosabbnak tartották, mint az egyenlőséget $(4,26)$. A szabadság értékelésében nem tért el a lányok $(4,52)$ és a fiúk $(4,47)$ véleménye, azonban az egyenlőség fontosságának megítélésében igen. A lányok szignifikánsan $(\mathrm{p}=0,004)$ fontosabbnak ítélték az egyenlőséget $(4,32)$, mint a fiúk $(4,2)$.

Fontos megjegyeznünk, hogy egy egyházi, görögkatolikus középiskoláról van szó, amely egy kelet-magyarországi kisvárosban található. Ezek a tények nyilvánvaló eltéréseket eredményezhetnek a kutatás tárgyainak megítélésében más nem vallásos, illetve más típusú településen élő fiatalokhoz képest. Colemannal kezdődően számos tanulmány hasonlította össze a katolikus és a nem katolikus iskolákat (Coleman és mtsai 1982). Egyes kutatók a tanulmányi sikeresség okát a katolikus identitás meglétében látták (Bryk és mtsai 1993). A katolikus iskolák eredményességét a közösséghez tartozás érzésében látták, ami különböző közösségi és vallásos tevékenységeken keresztül valósul meg (Inántsy - Pap 2018). A katolikus identitás és közösséghez tartozás ereje a katolikus fiatalok értékrendjére is hatást gyakorolhat más nem vallásos fiatalok értékrendjéhez képest.

A Magyar Ifjúság 2016 kutatás szerint a magyar fiatalok (16-19 éves korosztály) vallásossága szignifikánsan befolyásolja a szabadság $(\mathrm{p}=0,009)$ és az egyenlőség

\footnotetext{
${ }^{2}$ Az adatok forrása a Magyar Ifjúság Kutatás 2016. Az erre vonatkozó megállapításaink a tanulmányban a saját elemzésünk eredménye.
} 


\section{KÖZELKÉP}

( $\mathrm{p}=0,001$ ) fontosságának a megítélését. A szabadság értékét az egyház tanításai szerint élők $(4,58)$ és a maguk módján vallásosak $(4,55)$ fontosabbnak ítélték, mint a nem vallásos fiatalok $(4,46)$. Hasonló módon az egyenlőség értékét is fontosabbnak tartották az egyház tanításai szerint élők $(4,37)$ és a maguk módján vallásosak $(4,34)$, mint a nem vallásos fiatalok $(4,2)$. Látható tehát, hogy országosan a korcsoportban (16-19 éves) a vallásosság erősíti a szabadság és az egyenlőség értékének a fontosságát.

Pusztai Gabriella (2011) tanulmányában a pedagógiai ideológiák kapcsán beszél a fiatalok értékekhez való viszonyáról. Szerinte a nevelés során fontosnak tartott értékek a meghatározó tengelyének tűnik az egyéni-közösségi tengely, amelyen a vallásosabb fiatalok közelebb állnak a közösségi értékek pólusához, míg a nem vallásos fiataloknál az egyéni szabadság értéke felülírja a közösséggel szolidáris embereszményt (Pusztai 2011). Ebből következtethetünk arra, hogy a nem vallásos fiataloknak fontosabb lehet a szabadság absztrakt értéke, amely egy individualizált érték; míg a vallásos fiataloknak az olyan közösségi értékek lehetnek fontosabbak, mint az egyenlőség, a tolerancia és a szolidaritás.

Az igazságosságértelmezések magyarázhatják, legitimálhatják a társadalmi egyenlőtlenségeket. Pontosan emiatt olyan fontos a társadalmi egyenlőtlenségekkel kapcsolatban a társadalomban elő igazságosságeszmények megvizsgálása, mert ezen ideák alapján fogadja el vagy éppen küzd a társadalom a legkülönfélébb egyenlőtlenségek ellen (Csepeli - Neményi - Örkény 1992). Örkény Antal 1997-es szavai semmit sem veszítettek az aktualitásukból: „Ma Közép- és Kelet-Európában számtalan feladat vár megoldásra ... ezen feladatok közé tartozik az a cél, hogy helyreálljon az igazságosságban való hit, és nyilvánosan artikulálódjanak az eltérő igazságossági felfogások, valamint hogy létrejöjjenek az igazságot garantáló politikai és társadalmi intézmények" (Örkény 1997: 23).

\section{Minta és módszer}

Kutatásunkban egy kisebb, speciális populációt választottunk ki, egy kelet-magyarországi görögkatolikus középiskola tizenegyedikes és tizenkettedikes diákjait. A populáció minden egyes tagját bevontuk a mintába 2014 őszén és 2019 őszén is. A válaszadás önkéntes és anonim volt. A középiskola két felsőbb éves évfolyamából 2014-ben 100 főt, 2019-ben 105 főt sikerült megkérdeznünk. Az évfolyamokon két gimnáziumi osztály és egy szakgimnáziumi (2014-ben még szakközépiskolainak hívott) osztály volt mindkét adatfelvétel idején. A korosztály tagjai a korukból kifolyólag még sok, a kérdőívben szereplő kérdést nem tapasztaltak meg a saját életükben, ezért jól mutathatják be azokat a prekoncepciókat, amiket a társadalom, a család közvetített a fiataloknak. 


\section{KÖZELKÉP}

Kutatási módszerként kvantitatív kutatási módszert választottunk, azonban néhány kérdéskörnél mélyebb információkra is szükségünk volt, mely esetekben nem szerettük volna az alanyokat válaszkategóriákkal behatárolni, így a kérdőívben szerepel több nyitott kérdés is. Ezeket a nyitott kérdéseket utóbb kódoltuk, de az általuk kapott mélyebb információkat, sokszínű válaszokat az elemzés során idézetek formájában ismertetni fogjuk.

Kutatásunkban feltételezzük, hogy a megkérdezett fiataloknak az egyenlőség értéke fontosabb lesz a szabadság értékénél. Így hipotézisünk szerint az igazságosságnak az egyenlőségpárti felfogása fogja jellemezni a válaszoló fiatalokat. További hipotézisünk szerint a tolerancia és a szolidaritás értékének a megítélése alacsony szinten áll a fiataljaink értékrendszerében. Feltételezzük, hogy a lányoknak fontosabb lesz az egyenlőség, míg a fiúknak a szabadság értéke.

A populáció fő sajátossága tehát az iskola vallásos jellegéből adódik. A kutatást felölelő öt évben lényegesen csökkent a megkérdezett diákok vallásossága. Míg 2014ben a megkérdezett fiatalok 24\%-a válaszolta azt, hogy az egyház tanításai szerint él, ez az arány 2019-ben 8\%-ra csökkent. Míg 2014-ben a diákok 69\%-a a maga módján vallásosnak vallotta magát, addig 2019-ben 56\% mondta ezt. A kutatásunk eredményei szerint 2014-ben a fiatalok 93\%-a valamilyen formába vallásosnak tartotta magát, addig ez az arány 2019-re 64\%-ra csökkent. Ezzel párhuzamosan, míg 2014-ben a diákok 4\%-a válaszolta azt, hogy nem vallásos, addig 2019-re ez az arány 28\% lett. Azonban a megkérdezettek vallásossága így is erősebb a fiatalok országos átlagánál, ami egyértelműen a populáció speciális jellegéből adódik. A Magyar Ifjúság 2016-os adatai szerint a magyar fiatalok (16-19 éves korosztály) 5,8\%-a az egyház tanításai szerint él, 38,9\%-a a maga módján vallásos, így valamilyen formában vallásos a 16 és 19 éves kor közötti fiatalok 44,7\%-a. Míg a 55,3\%-uk nem vallásos (1. ábra).

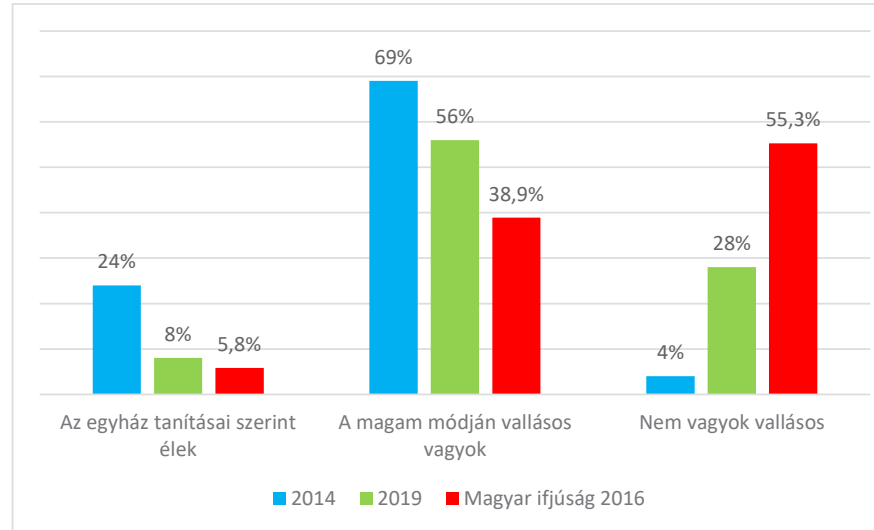

1. ábra. A vallásosság alakulása a megkérdezett fiatalok esetében a Magyar Ifjúság 2016 kutatás hasonló korú (16-19 éves korosztály) válaszadóval összehasonlítva (\%) (N = 199) Forrás: Magyar Ifjúság Kutatás 2016, saját szerkesztés 


\section{KÖZELKÉP}

A nemek tekintetében a lányok enyhe többsége figyelhető meg a kutatásunkban (2014-ben: 56\% lány, 44\% fiú, 2019-ben 55\% lány, 45\% fiú), ami nyilvánvalóan abból következik, hogy a minta 65\%-a (2014-ben), illetve 76\% (2019-ben) gimnáziumi képzésre jár, ahol a Magyar Ifjúság 2016 kutatás eredményei (16-19 évesek) szerint a lányok túlsúlyban (59,7\% lány, 40,3\% fiú) vannak országosan is. A populáció sajátossága még a vidéki, kisvárosi környezetből adódhat. Ugyanakkor a Magyar Ifjúság 2016 kutatás adatai alapján a vizsgált fiatal korosztály (16-19 éves) esetében a szabadság és az egyenlőség fontosságának megítélése nem mutat összefüggést azzal, hogy a fiataloknak milyen településtípuson van a lakhelye.

\section{A fiatalok igazságossággal kapcsolatos értékeinek vizsgálata}

A kvázi longitudinális kutatásunkban 2014-ben és 2019-ben a fiatalokat arra kértük, hogy állítsák fontossági sorrendbe az általunk felsorolt öt értéket (igazságosság, szabadság, szolidaritás, egyenlőség, tolerancia). Ezekből a válaszokból vontunk le következtetéseket a megkérdezett fiatalokra, amiket összevetettünk a korábbi kutatások eredményeivel.

Az értékek világa, az emberek viszonya az értékekhez (például az igazságossághoz) egy kevésbé kutatott területe ma a magyar társadalomtudományoknak, továbbá az értékek kutatását nehezíti, hogy problémás megragadni a lényegüket. Noha egy „adott kultúra látható részét alkotó szimbólumok, hősök, rítusok, valamint az ezeket megtestesítő gyakorlatok akár gyorsan is változhatnak, de a „hagyma” magját adó értékek lényegileg nem, vagy csak nagyon-nagyon lassan alakulnak át. A kultúra óriási nehézkedéssel óráról órára, napról napra, évről évre és évszázadról évszázadra reprodukálja önmagát" (Tóth 2009: 7). Eljutni az értékek magjáig szinte lehetetlen kutatói feladat, a lassan változó jellegük viszont lehetőséget ad arra, hogy évtizedekkel ezelőtti kutatások adatait is felhasználjuk az összehasonlításra, mert lényegi változás lassan következik be.

A társadalmi működés továbbélése szempontjából fontos kérdés, hogy mit gondolnak a fiatalok az igazságosság társadalmi berendezkedéséről, az embereket ért egyenlőtlenségekről és a szabadságról. Ha az ember egyenlőtlenségekről beszél, akkor egyenlőségről is beszél, és ha egyenlőségről beszél, akkor más értékekről is kell beszélnie, mert az értékek csak egymást támogatva, egymást behatárolva tudnak érvényesülni. A társadalmak működésében fontos szerepet játszó öt értékkel (szolidaritás, szabadság, egyenlőség, igazságosság, tolerancia) kapcsolatban arra kértük a diákokat, hogy állítsák ezeket az értékeket fontossági sorrendbe.

Erre azért volt szükség, hogy lássuk, a megkérdezett fiatalok az elméleti részben megkülönböztetett igazságosságértelmezések közül melyiket részesítik előnyben, a szabadság vagy az egyenlőség fontosabb-e nekik. Amennyiben a rawlsi értelmezéshez állnak közelebb a nézeteik, az kedvezne a társadalmi egyenlőtlenségek 


\section{KÖZELKÉP}

csökkentésének, mivel az értelmezés támogatja mindenféle egyenlőtlenség csökkentését. Míg ha a libertariánus értelmezéshez áll közelebb a fiatalok értékrendje, akkor az nagyobb szabadságvágyról és kisebb egyenlőségnövelő törekvésekről tesz tanúbizonyságot, ami nem kedvez az egyenlőtlenségek csökkentésének elvi szinten történő elfogadásának sem; így a társadalmi egyenlőtlenségek mérséklésének sem (Hayek 1991, Rawls 1997).

A kapott eredmények szerint a fiataljaink különböző értékrendszereket vallanak magukénak. Ez megfelel más értékkutatások eredményeinek is, amelyek azt mutatják, hogy napjainkban az értékek, értékrendszerek pluralizmusa, ellentmondásossága, ha úgy tetszik válsága figyelhető meg (Örkény 1997, Giddens 1999, Szabó-Tóth 2010). A negatív folyamatra Hankiss Elemér (1977) a 1970-es években felhívta a figyelmet, „negatív modernizációnak” nevezve el az alapvető értékek válságával járó folyamatokat. Ulrich Beck (2003) pedig a hagyomány végéről, a hagyomány utáni társadalomról ír, ahol az egyének már nem megváltoztathatatlan sorsként élik az életeiket. A folyamatot Beck individualizációnak nevezte el (Giddens 1999). Ezek alapján: „A magyar társadalomban erôteljesen eluralkodott egyfajta individualisztikus értékrend. Mindezek megnyilvánulnak abban is, hogy nincsenek mindenki által elfogadható közös értékek, célok, illetve az azok eléréséhez szükséges legális eszközök sokszor nem vezetnek sehova" (Szabó-Tóth 2010: 6). Az individualizáció megteremtette a szabadságot, a lehetőséget az egyének előtt, hogy olyan életet éljenek, amilyet csak akarnak; a lehetőségek sokasága, a hagyományok, a bejáratott támaszok hiánya, az egységes értékrend felborulása azonban nehézségként jelenhet meg ebben az új, hagyomány utáni világban (Giddens 1999).

Az öt alapvető emberi érték közül 2014-ben a kutatásban részt vevő fiatalok 29\%-a helyezte az első helyre az igazságosságot, ezt követte a szabadság 24\%-kal, majd a szolidaritás 19\%-kal. Az egyenlőség 16\%-ot, a tolerancia 12\%-ot kapott. 2019-ben az egyenlőséget 28\% tette az első helyre, így ez az érték erősödött meg legjobban az eltelt öt év alatt. A szabadságot pontosan ugyanakkora arány helyezte az első helyre, mint 2014-ben, 24\%. A szolidaritás 19\%-ot, az igazságosság 18\%-ot, a tolerancia pedig 11\%-ot kapott, így az igazságosság fontosságának a megítélése esett vissza a leginkább a diákoknál.

2014-ben az ötödik, utolsó helyre a megkérdezett fiatalok 35\%-a a toleranciát írta, míg 33\%-a a szabadságot. Itt a következő érték volt az egyenlőség 16\%-kal, és mindössze 9\%-ot és 7\%-ot kapott az igazságosság és a szolidaritás az utolsó helyen. 2019-ben a legnagyobb arányban szintén a toleranciát tették a diákok (32\%) a legkevésbé fontos helyre. A tanulók 29\%-a pedig a szabadságot írta ide. Ezt követték a szolidaritás 20\%-kal, az igazságosság 10\%-kal és az egyenlőség 9\%-kal. Érdekesség, hogy a szabadságot 24\% (2014-ben és 2019-ben is) vélte a legfontosabb értéknek, míg a tanulók 33\%-a (2014-ben) és 29\%-a (2019-ben) írta az utolsó helyre, ami a legnagyobb szórást eredményezi az öt érték között. Így hosszú távon a szabadság 


\section{KÖZELKÉP}

fontosságának a megítélése tűnik a legellentmondásosabbnak az értékek közül (2. ábra).

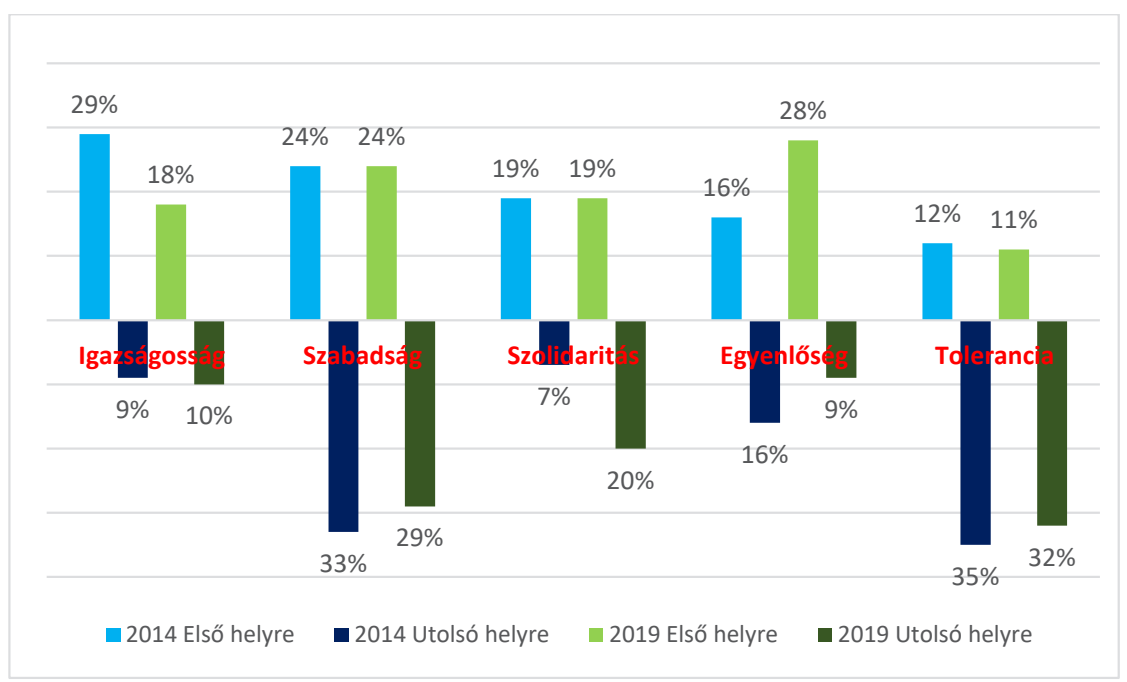

2. ábra. Az öt érték sorrendje (az első és az utolsó helyezések alapján) (N = 194) Forrás: Saját szerkesztés

Ha értékenként megnézzük a kapott sorszámokat, és ezeket átlagoljuk, akkor kaphatunk egy olyan egy és öt közé eső számot, mely azt mutatja, hogy a diákoknak mennyire fontos egy-egy érték a másik négyhez viszonyítva. A mutatószám minél közelebb van az egyhez, annál fontosabb, minél közelebb van az öthöz, annál jelentéktelenebb a többi értékhez viszonyítva. Az így kapott átlagok alapján 2014-ben a legfontosabb érték a fiataloknak az igazságosság 2,49-es átlaggal. A következők pedig sorrendben: a szolidaritás $(2,74)$, az egyenlőség $(3,02)$, a szabadság $(3,21)$ és a tolerancia $(3,49)$. 2019-ben az igazságosságot felváltotta az első helyen az egyenlőség 2,45-ös átlaggal. Ezt követi sorrendben az igazságosság $(2,86)$, a szabadság $(3,06)$, a szolidaritás $(3,14)$ és a tolerancia $(3,48)$ (3. ábra). A tolerancia értékével kapcsolatban más kutatások is megállapították, hogy számos területen alacsony, és csökken a magyar társadalom toleranciaszintje (Kapitány - Kapitány 2012). 


\section{KÖZELKÉP}

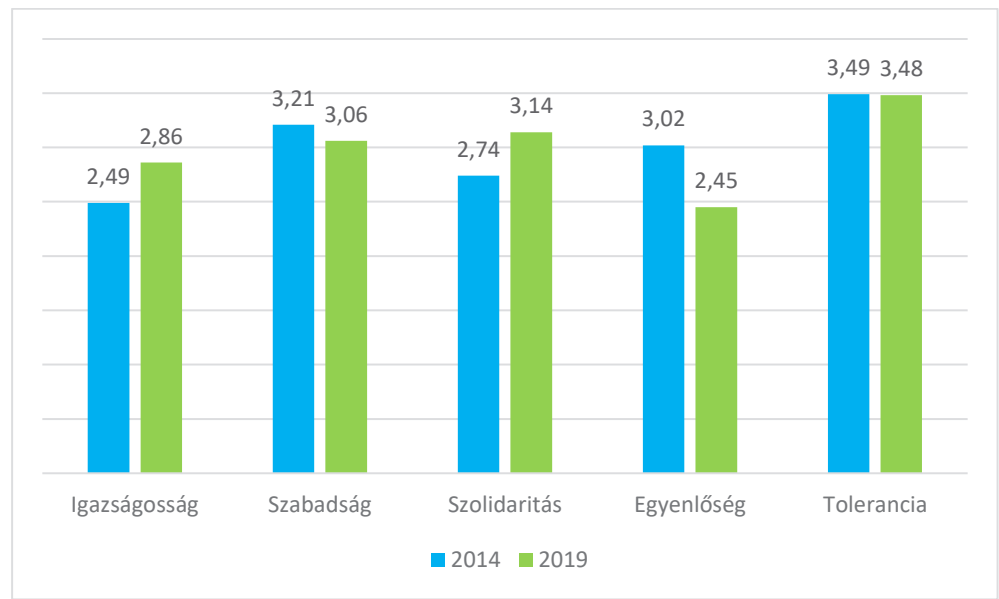

3. ábra. Az értékek átlagai $(\mathrm{N}=194)$

Forrás: Saját szerkesztés

Az értékek közül 2014-ben egyértelműen az első helyezést érte el minden mutató alapján az igazságosság. A második legfontosabb érték a fiataljaink szerint a szolidaritás volt akkor. Harmadik helyen az egyenlőség végzett, negyedik helyen a szabadság, az ötödik helyen pedig a tolerancia. 2019-ben átvette a vezetést egyértelműen az egyenlőség, míg a második helyen a szabadság végzett. Ugyanakkor a válaszok alapján a szabadság volt a legmegosztóbb. A legnagyobb eltérés ennek az értéknek a megítélésében volt. A harmadik helyen az igazságosság végzett a középmezőnyben. A negyedik a szolidaritás lett, az ötödik pedig a tolerancia. Azt láthatjuk, hogy öt év alatt az igazságosság helyét átvette az egyenlőség, ami egyértelműen az egyenlőségpárti igazságosság felé elmozdulást jelentheti a megkérdezett fiataloknál. A szabadság megítélése valamelyest javult összességében, de még mindig ez a legellentmondásosabb érték. Az igazságosság láthatóan fontos továbbra is a diákoknak. Míg a szolidaritás veszített a jelentőségéből, a tolerancia pedig továbbra is a lista végén szerepel. Az igazságosság szempontjából ez a változás egyértelműen az egyenlőségpárti igazságosság felé való elmozdulást bizonyíthatja a megkérdezett fiataljaink körében, azaz számukra az igazságosabb, ami az egyenlőség felé vezeti a társadalmi viszonyokat.

Ha elfogadjuk azt az általános élettapasztalatot, hogy sokszor akkor válik valami fontossá, amikor érzékelni kezdjük annak hiányát, akkor az egyenlőség értékének növekedése elvi szinten összefügghet a megkérdezett fiatalok azon érzetével, hogy 2014 és 2019 között csökkent hazánkban és globálisan a világban is az egyenlőség (Kolosi - Tóth 2018, Szigetvári 2016). Napjainkban annyira lecsökkentek a távolságok a világunkban, hogy a fiataljaink egyenlőség iránti nézeteit ugyanúgy erősítheti 


\section{KÖZELKÉP}

egy távoli országban látott szélsőséges egyenlőtlenség és szegénység, mintha a szűkebb környezetükben, hazájukban látják ugyanezt. Továbbá ennek az érzetnek nem szükségszerűen kell találkoznia a valós statisztikai mutatókkal, elég, ha a hétköznapi ember számára ez a kép alakul ki a körülötte lévő világról. Az egyenlőség értékének erősödéséhez vezethet a közismert kádári nosztalgia is, melyet a kapitalizmus lehetőségei és veszélyei befolyásolhattak hazánkban a rendszerváltás óta, annak megfelelően, hogy egy-egy egyén, család a lehetőségeket vagy a veszélyeket élte át hangsúlyosabban az elmúlt évtizedekben. A megkérdezett fiatalok a felmenőiktől vehetik át az egyenlőség eszményével átszőtt idők nosztalgiáját.

2014-ben azt láttuk, hogy összességében az egyenlőség jobb eredményeket ért el, mint a szabadság, ugyanakkor a szabadságnak a megítélése szélsőségesebb volt. Úgy tűnt akkor, hogy van egy réteg, akinek nagyon fontos a szabadság (24\%), de a válaszoló fiatalok nagyobbik része egyértelműen az egyenlőség eszménye mögé helyezte a szabadság értékét. Ez a tendencia 2019-re felerősödött. Továbbra is van egy kisebbség, akinél a szabadság a legfontosabb (24\%), ugyanakkor az egyenlőség megítélése egyértelműen fontosabb lett az elmúlt öt év alatt, és a legfontosabb értékké vált. Ezekből az adatokból úgy látszik, hogy a fiataljaink 2014-hez képest még inkább a rawlsi, szabadság- és egyenlőségpárti igazságosságot részesítik előnyben, a libertariánus szabadságpárti, egyenlőségellenes igazságossággal szemben. Ez az eredmény megfelel a magyar társadalom korábbi kutatásokban feltárt álláspontjának, ugyanis a magyarok többsége szerint az egyenlőség igazságos (Csepeli - Neményi - Örkény 1992). A fiataljaink 24\%-a (2014-ben és 2019-ben is) valószínűsíthetően annak a kisebbségnek a tagjai, akik szerint az egyenlőség igazságtalan és az egyenlőtlenség az igazságos (Csepeli - Neményi - Örkény 1992). Más kutatásokból is úgy tűnik, hogy a magyarok „egyenlőségpártiak”: „a magyarok stabilan, a többi országhoz képest lényegesen magasabb arányban értenek egyet azzal, hogy Magyarországon »túl nagyok a jövedelmi egyenlötlenségek” (Tóth 2009: 38). Az egyenlőség ilyen mértékű támogatottsága kedvezhet a társadalmi egyenlőtlenségeket felszámolni kívánó törekvések legitimitásának.

Ugyanakkor a Magyar Ifjúság 2016 kutatás adatai szerint a 16 és 19 év közötti fiatalok fontosabbnak ítélték meg a szabadságot $(4,5)$, mint az egyenlőséget $(4,26)$ $(\mathrm{p}=0,000)$. A megkérdezett fiataljainkra ennek pont az ellenkezője igaz: az egyenlőséget preferálják a szabadsággal szemben. Ennek az lehet az oka, hogy a megkérdezett fiatalok között a lányok felülreprezentáltak voltak, akik szignifikánsan egyenlőségpártibbak a 16 és 19 éves korosztályban a fiúknál a Magyar Ifjúság 2016 adatai alapján. Továbbá láthattuk a 2016-os ifjúságkutatás adataiból azt is, hogy a vallásosság pozitív hatással van mind az egyenlőség, mind a szabadság fontosságának a megítélésére is. A válaszoló fiataljaink pedig vallásosabbak az országos átlagnál.

Az értékek preferálása nem mutatott kapcsolatot az egyének nemével. Bár 2014-ben a szabadság értékével kapcsolatban a kereszttáblában felfedezhetők sajátosságok, annak ellenére, hogy ebben az esetben sem beszélhetünk szignifikáns 


\section{KÖZELKÉP}

kapcsolatról $(0,128)$. Feltűnő adat azonban, hogy a fiúknak sokkal jobban szórnak a szabadság fontosságára adott értékeik, míg a lányok magasabb arányban helyezték a szabadságot a legutolsó értéknek. 2014-ben a fiúk 19\%-ánál szerepel az utolsó helyen a szabadság, míg a lányoknak a 43,6\%-a szerint ez az ötből a legkevésbé fontos érték.

2019-re ez a két érték közelített egymáshoz: 25\%-ra nőtt azoknak a fiúknak az aránya, akik szerint a szabadság a felsorolt öt értékből a legkevésbé fontos, míg 32,7\%-ra csökkent a hasonlóan vélekedő lányok aránya. A szabadság értékére adott átlagok alapján sincs szignifikáns eltérés a fiúk $(2,89)$ és a lányok $(3,2)$ között, így a szabadság fontosságának megítélése nem függ a megkérdezett fiatalok nemétôl. Nem így az egyenlőség és a tolerancia, ahol szignifikáns kapcsolat volt kimutatható a nemmel. Az egyenlőség értékeinél látható, hogy az első helyre magasabb arányban sorolták a lányok az egyenlőséget, viszont a második és a harmadik helyre már a fiúk értékelték sokkal magasabb arányban, mint ahogy a fiúk sokkal kisebb arányban helyezték az utolsó helyre az egyenlőséget, mint a lányok, akiknél nagyobb szórást mutatott ez az érték, míg a fiúk leginkább az első három helyre helyezték el az egyenlőséget (4. ábra). Az egyenlőségre adott átlagok nem mutatnak szignifikáns különbséget $(\mathrm{p}=0,116)$, de a fiúk átlagai alacsonyabbak $(2,23)$, mint a lányoké $(2,64)$, azaz a fiúk fontosabbnak ítélték meg az egyenlőséget.

Ez ellentmond a Magyar Ifjúság 2016 kutatás adatainak, ahol a lányoknak szignifikánsabban fontosabb volt az egyenlőség, mint a fiúknak, de a kutatás adataiból az is kiolvasható, hogy a vallásosság mind az egyenlőség fontosságát, mind a szabadság fontosságát erősítette. Az adatainkból így az látszik, hogy az erősebb vallásosság megszüntette a lányok és fiúk között az egyenlőség szignifikánsan eltérő megítélését, és a kutatásunkban a fiúknak ugyanolyan fontos ez az érték, mint a lányoknak.

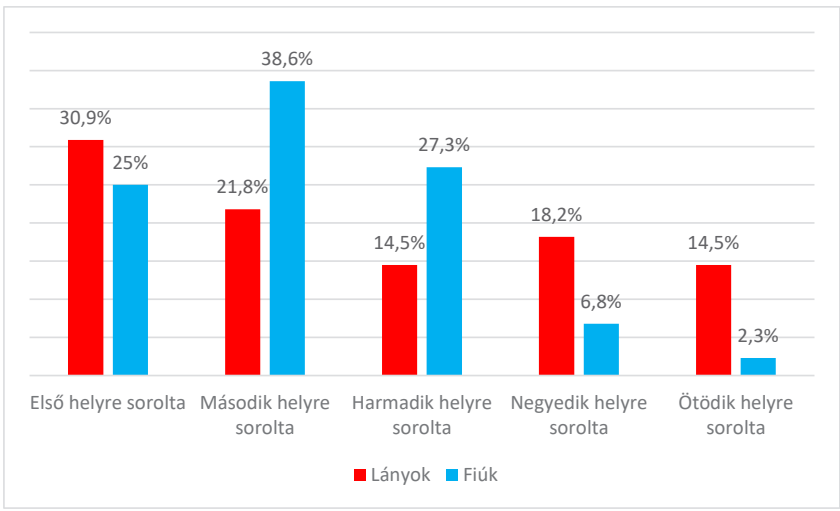

4. ábra. Az egyenlőség helyezései nemenként a másik négy értékhez viszonyítva 2019-ben (\%) (N = 195) Forrás: Saját szerkesztés 


\section{KÖZELKÉP}

A tolerancia értéke viszont egyértelműen a lányoknak a fontosabb. Az első három helyre magasabb arányban helyezték ezt az értéket, mint a fiúk, míg a két utolsó helyre a fiúk sorolták magasabb arányban. Így egyértelműen látszik, hogy a lányok elfogadóbbak másokkal, a mássággal szemben, azaz toleránsabbak (5. ábra). A Magyar Ifjúság 2016 kutatásban azt kérdezték a fiataloktól, hogy mennyire fontos az előítéletektől való mentesség, ami hasonlít a tolerancia értelmezéséhez. Az országos kutatás eredményei alapján is elmondható a 16 és 19 éves korosztály esetében, hogy a lányok $(4,31)$ szignifikánsan $(p=0,011)$ fontosabbnak tartják az elöítéletmentességet, mint a fiúk $(4,21)$. Arra, hogy a lányok toleránsabbak és szociálisan érzékenyebbek, mint a fiúk, több hazai kutatás is felhívta már a figyelmet (Thun 2007, Markos 2020).

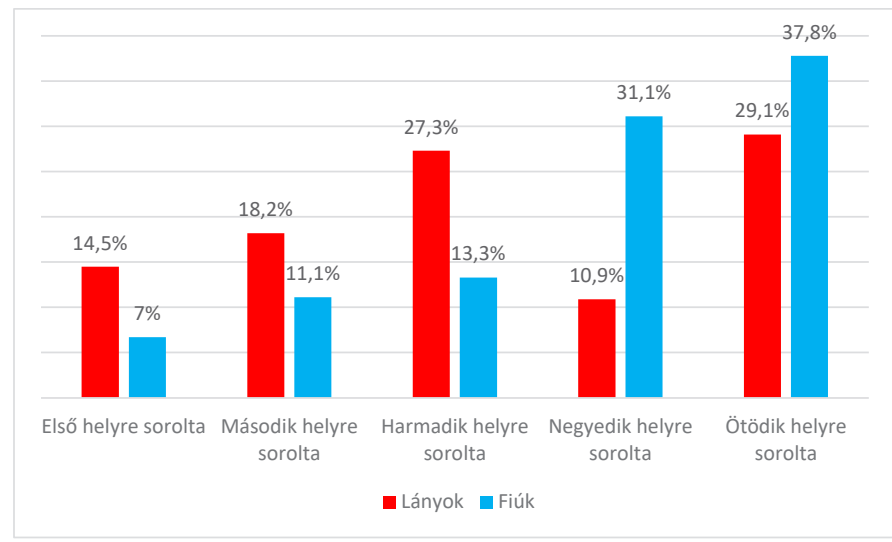

5. ábra. A tolerancia helyezései a másik négy értékhez viszonyítva 2019-ben (\%) (N = 194) Forrás: Saját szerkesztés

\section{Összegzés}

A tanulmányunkban a jó társadalom kialakításához szükséges értékeket kívántuk vizsgálni. Az ókori görög filozófusokra visszavezetve, az volt a kiindulópontunk, hogy a jól múködő társadalomnak elsősorban igazságosnak kell lennie. Az elméleti részben az igazságosság filozófiai vizsgálatát és a szabadsággal és az egyenlőséggel kapcsolatos értékszociológiai elméleteket vettük sorba. Ezeken keresztül kétféle igazságosságot különböztettünk meg. Az egyiknél a szabadság jelenti az igazságosságot, az egyenlőség pedig káros; a másiknál viszont a szabadság és az egyenlőség együtt alkotja az igazságosságot.

Hazai kutatások fényében elhelyeztük a magyar társadalmat a kétféle igazságosságértelmezés tükrében, és megállapítottuk, hogy hazánkra inkább mind a társada- 


\section{KÖZELKÉP}

lom egészére, mind a fiatalokra „az egyenlőség igazságos”-felfogás a jellemzőbb. Tehát a magyarok inkább azt vallják, hogy az igazságosság értékéhez nemcsak szabadságra, hanem egyenlőségre is szükség van. A Magyar Ifjúság 2016 kutatása szerint különösen igaz ez a lányokra, akiknek fontosabbnak tűnik az egyenlőség absztrakt értéke, mint a fiúknak. Ugyanakkor ebben a kutatásban a fiatalok (16-19 korcsoport) összességében a szabadságot valamennyivel fontosabbnak ítélte meg, mint az egyenlőséget. Ebből is látszik, hogy a fiúk a szabadságot fontosabbnak tartják, mint a lányok. A hazai ifjúságkutatásból azt is láthattuk, hogy a vallásosság erősíti mind a szabadság, mind az egyenlőség értékének a megítélését. Míg más kutatások szerint (Pusztai 2011) a vallásosság hatással lehet az egyenlőség preferálására, míg a nem vallásosság a szabadság értékének erősítéséhez vezethet. A válaszoló fiataljaink vallásossága a kutatás öt évében csökkent, de még így is a Magyar ifjúság 2016 kutatásban kapott országos átlagoknál az adott korosztályt tekintve lényegesen magasabb.

Az általunk felsorolt öt érték értékeléséből látszik, hogy a válaszoló fiatalok számára 2014-ben a legfontosabb érték egyértelműen az igazságosság, míg 2019-ben ez az egyenlőség lett. Az igazságosság visszacsúszott a középmezőnybe, így a szabadság is megelőzi 2019-re, aminek a legellentmondásosabb a megítélése. A szolidaritás öt év alatt az utolsó előtti helyre került, miközben az utolsó, legkevésbé fontos érték az ötből továbbra is a tolerancia. Az igazságosság két típusának megítélése szempontjából az egyenlőség és a szabadság értékeinek az egymáshoz viszonyított megítélése a lényeges. Ebből a szempontból a tanulmányban azt láthattuk, hogy az egyenlőség megelőzte a szabadságot. A szabadságnak viszont nagyobb volt a szórása, így megállapíthatjuk, hogy egy egynegyedes kisebbségnek ez a legfontosabb érték, de a többiek jóval kevésbé ítélték fontosnak, mint az egyenlőséget. Így megállapítható, hogy a megkérdezett fiatalok háromnegyede az egyenlőségpárti igazságosság felé hajlik.

A válaszok nemenkénti bontásában 2014-ben megállapítottuk, hogy a lányoknak kevésbé fontos a szabadság értéke, mint a fiúknak, ami megegyezik az országos eredményekkel. 2019-re ezek a különbségek eltűntek, és a lányok szabadságértékelése nőtt, míg a fiúké csökkent, így szűkült a kettőjük közötti olló. Ebben az esetben nincs szignifikáns különbség a nemek között. Ezzel párhuzamosan a fiúknál egyértelműen nőtt az egyenlőség értéke, míg a lányoknál csökkent. Így a fiúknak szignifikánsan fontosabb az egyenlőség értéke, mint a lányoknak, ami ellentmond a Magyar Ifjúság 2016 kutatás 16 és 19 éves fiataljai eredményeinek, ugyanis országosan a lányok az egyenlőségpártibbak. Az eltérést egyértelműen a megkérdezett fiúk vallásossága eredményezheti, ami olyan erővel hat az egyenlőség fontosságának megítélésére, hogy megfordítja az országos tendenciát. Tehát a vallásosság a fiúkra nagyobb hatással van az egyenlőség megítélésében, mint a lányokra, akik a kutatások szerint alapból egyenlőségpártibbak. A vallásosság a Magyar Ifjúság 2016 kutatásban is szignifikáns kapcsolatot mutatott az egyenlőség fontosságának megítélésében. A lányok viszont szignifikánsan toleránsabbak lettek 2019-re, mint a fiúk. Ebben megegyeznek a Magyar Ifjúság 2016 kutatás hasonló korú lányaival. 


\section{KÖZELKÉP}

Kutatásunk hipotézise beigazolódott, miszerint a megkérdezett fiataloknak az egyenlőség értéke fontosabb lesz a szabadság értékénél. Ezzel együtt az is bizonyítást nyert, hogy az igazságosságnak az egyenlőségpárti felfogása jellemzi a válaszoló fiatalokat. További eredményünk szerint a tolerancia és a szolidaritás értékének a megítélése alacsony szinten áll a fiataljaink értékrendszerében. Ugyanakkor a lányoknak szignifikánsan fontosabb a tolerancia, mint a fiúknak. Az utolsó két hipotézisünk viszont nem igazolódott be, ugyanis az eredményeink azt mutatják, hogy a lányok és a fiúk között nincs különbség a szabadság értékének megítélésében. Ugyanakkor a fiúknak szignifikánsan fontosabb az egyenlőség értéke, mint a lányoknak.

További vizsgálatok segíthetik a vallásosság igazságosságérzetet befolyásoló hatásának kimutatását, ezenbelül a szabadság és az egyenlőség absztrakt értékeinek a megélését egy vallásosabb közegben, és azt, hogy a vallásosság hogyan befolyásolja a fiatalok összességében meglévő értékrendszeri különbségeit. Mindezek időbeli követése is fontos, hogy tendenciákat lehessen felállítani mind a fiatalok, mind a vallásos fiatalok igazságérzetének változásairól, amiből következtethetünk az össztársadalom igazságosságeszményének a lassú változásaira, melynek társadalmipolitikai nyomon követése lehet a kulcsa a társadalom igazságos müködéséhez, ami a feltétele egy jó működésnek, az értékteremtésnek és a fennmaradásnak.

\section{Irodalom}

Andorka R. (2006): Bevezetés a szociológiába. Osiris Kiadó, Budapest

Arisztotelész (1987): Nikomakhoszi etika. Európa Kiadó, Budapest

Bakacsi Gy. (2012): A globe-kutatás kultúraváltozóinak vizsgálata faktoranalízis segítségével (Cultural variables of the GLOBE research computed by factor analysis). Vezetéstudomány, 63(4): 12-22.

Beck, U. (2003): A kockázat-társadalom. Századvég Kiadó, Budapest

Bryk, A. - Lee, V. - Holland, P. (1993): Catholic schools and the common good. Cambridge, MA: Harvard University Press

Bujalos I. (2005): Igazságosság Amerikában. Hogyan gondolta tovább Michael Walzer John Rawsl elméletét. Esély folyóirat, 2005/3: 3-28.

Bujalos I. (2007): Az angol utilitarizmus a 19. században. Magyar Tudomány, 2007/5. 636.

Bujalos I. (2008): Posztmodern liberalizmus. Kossuth Egyetemi Kiadó, Debrecen

Coleman, J. - Hoffer T. - Kilgore S. (1982): High School Achievement: Public, Catholic and Private Schools Compared. New York, Basic Books

Csákó M. (2007): Tizenévesek demokráciaképe. Politológus Vándorgyülés, Pécs, 2007. június 22. Konferencia előadás-kivonat 


\section{KÖZELKÉP}

Csepeli Gy. - Neményi M. - Örkény A. (1992): Jövőtlen értékeink. Az igazságosság és igazságtalanságérzet alakzatai Magyarországon 1991-ben. In: Andorka R. - Kolosi T. - Vukovich Gy. (szerk.): Társadalmi riport, TÁRKI, Budapest, 334-357.

Fromm, E. (2002): Menekülés a szabadság elől. Napvilág, Budapest

Giddens, A. (1999): Risk and responsibility. The Modern Law Review, 62(1): 1-10.

Hankiss E. (1977): Érték és társadalom. Tanulmányok az értékszociológia világából. Magvető Kiadó, Budapest

Hayek, F. A. (1991): „Szociális” vagy elosztási igazságosság. In: Ferge Zs. - Lévai K. (szerk.): A jóléti állam. T-Twins K., Budapest

Hofmeister-Tóth Á. (2016): Fogyasztói értékek, trendek és magatartás. Vezetéstudomány, 67. Marketingtudományi Különszám

Hofstede, G. (é. n.): What about Hungary? Forrás: https://www.hofstedeinsights. com/country/hungary/ (Utolsó letöltés: 2020. 01. 20.)

Inántsy-Pap Á. (2018): Kontinuitás és pedagógiai érzékenység - A magyarországi görögkatolikus iskolák társadalmi funkciója. Debreceni Egyetem, Doktori disszertáció. https://dea.lib.unideb.hu/dea/bitstream/handle/2437/264687/inantsy_pap_agnes_disszertacio_titkositott.pdf?sequence=1\&isAllowed=y (Utolsó letöltés: 2020. 01.19.)

Inglehart, R. - Baker, W. E. (2000): Modernization, cultural change and the pesistence of cultural values. University of Michigan: American Sociological Review, 65(1) (February): 19-51.

Inglehart, R. (1997): Modernization and postmodernization. Cultural, economic, and political change in 43 societies. New Jersey, Princeton University Press

Inglehart, R. - Welzel, Ch. (2005): Modernization, cultural change and democracy. New York and Cambridge, Cambridge University Press

Kapitány Á. - Kapitány G. (2012): Konszenzusok és ambivalenciák. Reflexiók egy értékkutatás eredményeihez. Szociológiai Tanulmányok, 2012/1. 199-223.

Kolosi T. - Tóth I. Gy. (2018): Társadalmi riport 2018. TÁRKI, Budapest

Kovács K. (2012): Az egyenlőség felé. A hátrányos megkülönböztetés tilalma és a támogató intézkedések. L'Harmattan, Budapest

Markos V. (2020): Úton a felelős állampolgári lét felé - Az iskolai közösségi szolgálat közvetlen és közvetett hatásai. Debreceni Egyetem Felsőoktatási Kutató és Fejlesztő Központ, Debrecen

Mill, J. S. (1980): A szabadságról; Haszonelvüség. Magyar Helikon, Budapest

Murányi I. (2016): Tizenévesek előítéletessége és demokráciához való viszonya. In: Nagy Á. - Oross D. (szerk.): Ifjúságügy - Szöveggyújtemény I. UISZ Alapítvány, Budapest 


\section{KÖZELKÉP}

Neumann-Bódi E. - Hofmeister-Tóth Á. - Kopp M. (2008): Kulturális értékek vizsgálata a magyar társadalomban Hofstede kulturális dimenziói alapján. In: Kopp M. (szerk): Magyar lelkiállapot 2008. Semmelweis Kiadó, Budapest. 365-373.

Örkény A. (1997): Hétköznapok igazsága. Új Mandátum, Budapest

Pál E. (2016): Értékkutatások - a fiatalok számára fontos értékek. EMOK - XII. Országos Konferencia - Hitelesség és Értékorientáció a marketingben, Debrecen

Platón (2008): Állam. Cartaphilis, Budapest

Pusztai G. (2011): Vallásosság és pedagógiai ideológiák. Educatio, Budapest. 20(1): 48-61.

Rawls, J. (1997): Az igazságosság elmélete. Osiris, Budapest

Schwartz, S. H. (2003): Univerzáliák az értékek tartalmában és struktúrájában. Elméleti előrelépések és empirikus próbák húsz országban. In: Váriné Szilágyi I. (szerk.): Az értékek az életben és a retorikában. Akadémiai Kiadó, Budapest, $105-154$.

Szabó-Tóth K. (2010): ...de mi van a férfiakkal? Férfiszerepek a változó Magyarországon. Forrás: https://www.haromkiralyfi.hu/upload/files/dr_-szabo-toth-kinga ---_de-mi-van-a-ferfiakkal.pdf (Utolsó letöltés: 2020. 12. 23.).

Szigetvári T. (2016): Globális egyenlőtlenség és nemzetközi fejlesztéspolitika a katolikus társadalmi tanítás tükrében. KÖZ-GAZDASÁG, 11(4): 143-156.

Thun É. (2007): A neveléstudományi és oktatástudományi paradigmákról a társadalmi nemek elméleti kereteibe foglalva. Educatio, 2007/4: 623-636.

Tóth I. Gy. (2005): Jövedelemeloszlás. A gazdasági rendszerváltástól az uniós csatlakozásig. Budapest, Andorka Rudolf Társadalomtudományi Társaság - Századvég Kiadó

Tóth I. Gy. (szerk.) (2008): TÁRKI - UniCredit Európai Társadalmi Jelentés 2008. TÁRKI - UniCredit Bank, Budapest

Tóth I. Gy. (2008): The demand for redistribution. A test on Hungarian data. Sociologický Casopis. Czech Sociological Review, 44(6): 491-509.

Tóth I. Gy. (2009): Bizalomhiány, normazavarok, igazságtalanságérzet és paternalizmus a magyar társadalom értékszerkezetében. TÁRKI, Budapest

Tóth I. Gy. (2010): A társadalmi kohézió elemei: bizalom, normakövetés, igazságosság és felelösségérzet - lennének... TÁRKI, Budapest

Törőcsik M. (2016): A fogyasztói magatartás új tendenciái. MTA Kézirat, Budapest

Ward, T. - Lelkes O. - Sutherland, H. - Tóth I. Gy. (2009): European inequalities. Social inclusion and income distribution in the European Union. TÁRKI, Budapest. www.tarki.hu/en/publications/EI/european_inequalities09_toc.pdf (Utolsó letöltés: 2020. 02. 04.) 